Tér és Társadalom 20. évf. 2006/2. 1-21. p.

Tér és Társadalom

\title{
RÉGIÓK OROSZORSZÁGA
}

\author{
(Russia of the Regions) \\ HORVÁTH GYULA
}

Kulesszavak:

Oroszország terileti killönbségek gazdasági térszerkezet regionális politika

Oroszország a Szovjetuniótól térben kïlönlegesen egyenlötlen gazdasági szerkezetet örökölt. A terilleti fejlödést befolyásoló tôkeakkumuláció és ipartelepítés a kormmunista kormányzás évtizedeiben kurkítozont szúmú régiót érintett. A birodalom széthullását követôen a legfejlettebb és a legszegényebb régiók közżti killönhségek tovább növekeditek. A tanulmauny a régiók közötti terilleti külänbségeket és az azokat befolyásoló tényezöket elemzi, vázalja a markíns regionális problëmúkat. és ismerfeti a regionális politika fontosabb dokumentumait.

\section{Bevezetés}

A Szovjetunió 1991. évi felbomlását követöen a piacgazdaságra való áttéréssel és az egységes gazdasági tér darabjaira hullásával a regionális különbségek még eróteljesebbekké váltak. A gazdasági liberalizáció hatásai eltérô módon érvényesültek az ország egyes térségeiben. A mély gazdasági és a hosszan elhúzódó politikai válság az ország valamennyi régiójában éreztette a hatását, a területfejlesztés döntỏ forrását jelentő állami beruházások minimálisra apadtak, a köztársaságọ közötti korábbi szoros gazdasági kapcsolatok megszakadtak. Az ipari termelés a legnagyobb mértékben az európai központi, a déli és a távol-keleti régiókban csökkent, az eróforrásokban gazdag szibériai és az észak-oroszországi területeken az ipar visszaszorulása csekélyebb - bár még mindig jelentős - mértéket mutat (2. ábra). A változások nyertesei kizárólag Oroszország európai központjai lettek. Moszkva és Szentpétervár fejlödése posztindusztriális vonásokat mutat, az új piaci szervezetek (pénzintézetek, üzleti szolgáltatási intézmények, exportvállalkozások) meghatározó hányada e két városban tálálható. Az ország régiói ko̊zül különösen azok kerültek súlyos helyzetbe, amelyek gazdaságát gigantikus vállalati koncentrációk, egyoldalú specializáció jellemezte (1. táblázat).

\section{TÁBLÁZAT}

A különbözö fejlettségii régiókban élö népesség megoszlása Oroszországban, 1993 (Distribution of the Russian Population in 1993 Based on Regional Development Level)

\begin{tabular}{lcc}
\hline \multicolumn{1}{c}{ Régiótipus } & $\begin{array}{c}\text { A népesség száma, } \\
\text { ezer fö }\end{array}$ & $\begin{array}{c}\text { Megoszlâs, } \\
\text { százalék }\end{array}$ \\
\hline Elmaradott & 34745 & 23,4 \\
Depressziós & 35073 & 23,7 \\
Stagnáló (átmeneti) & 30527 & 20,6 \\
Fejlett & 47900 & 32,3 \\
\hline Összesen & 148245 & 100,0 \\
\hline
\end{tabular}

Forrás: Bandman-Guzner-Seliverstov, 1996. 211-243. o.; Bülov-Smirjagin, 1996. 181-183. o. alapján a szerzōo számításai. 


\section{Regionális átalakulás Oroszországban}

A birodalom széthullása után az Oroszországi Föderációban jelentős regionális átrendeződés vette kezdetét. Az elmúlt másfél évtizedben az ország gazdasági és térbeli szerkezetét befolyásoló változások alapvetó irányai a következők voltak:

- a Szovjetunió összeomlása után kialakult új állampolitikai helyzet (a korábbi belsö perifériák külső perifériákká váltak),

- a tervgazdaság felszámolása, az új piaci viszonyok kialakulása,

- az orosz gazdaság külpiaci nyitása,

- Oroszország új típusú regionalizálása, a gazdaság átalakulása számtalan, közigazgatási határokon átnyúló szerveződéseket eredményezett, például az energetikai iparban, a közlekedésben,

- az urbanizáció új szakaszának kibontakozása, amelyben a városi életmódot és infrastruktúrát már nem közvetlenül az ipari és technológiai követelmények, hanem a modern. környezetbarát és az életkörülmények minőségi javítását szolgáló szempontok alakítják.

A piacgazdaságra való áttérés legérzékenyebben az ipari ágazatokat érintette. Az ipari termelés az 1990-es évek közepére a felére csökkent. A termelés-visszaesés régiónként igen különböző mértékủ volt. Az Észak-kaukázusi régióban 59\%-kal, a Kalinyingrádi területen $63 \%$-kal, az Uralon túli régiókban is közel $50 \%$-kal mérséklődött az ipari termelési érték. Az alsóbb szintü területi egységeket (oblasztyokat) szemlélve még drámaibb csökkenést tapasztalhatunk. Ipari növekedés mindössze 17 területi egységre volt jellemző. A regionális differenciálódás fö mozgatóereje az ipar ágazati szerkezetének átalakulása volt. A legnagyobb (50-70\%-os) visszaesés a textiliparban, a múszeriparban, a vegyiparban és a fafeldolgozásban következett be. Ezek, illetve a jellegtelen telephelyiparra alapozott gazdaságú régiók - elsősorban a nemzetiségek által lakott perifériákon - mutatják a legmélyebb depressziós vonásokat: A soknemzetiségű autonóm köztársaságokban a munkanélküliségi ráták elérik a 30\%-ot, miközben a munkanélküliség a nyersanyagtermelö körzetekben 4-5\%-ot tesz ki. A lakossági jövedelmek tíz-tizenötszörös különbséget mutatnak e két térségtípust összehasonlítva. Az ország régióinak egyharmadában a lakosság fele létminimum alatti jövedelemből él. A gazdasági ágazatok munkajövedelmei is jelentős eltéréseket eredményeztek: A fütőanyagiparban dolgozók átlagkeresetei a nemzetgazdasági átlag háromszorosát, a könnyủipari bérek a felét érik el.

A cári parancsuralmi rendszer és a tervgazdasági logika alapján létrehozott régiók (oblasztyok) a nyílt piaci viszonyok között komoly problémákkal találták magukat szemben. Az orosz közigazgatási egységek jelentös része képtelen volt a piaci követelmények diktálta versenyfeltételeknek eleget tenni. Mindenekelött azok a települések kerültek nehéz helyzetbe, amelyek korábbi mủködését geopolitikai szempontok határozták meg (hadiipari komplexumok telephelyei, zárt katonai körzetek voltak), vagy fejlődésüket egyetlen óriásvállalat befolyásolta. Szakértöi becslések 
szerint a kedvezôtlen területszervezési körülmények következtében a bruttó hazai termék vesztesége évente $2-3 \%$-ot tett ki.

A gazdaságot befolyásoló piaci optimalizációs kényszer és a népesség spontán mozgása a területi folyamatok szervezetlenségéböl adódóan jelentős nyomást gyakorolt az infrastrukturális hálózatokra a feltörekvő régiókban, hatalmas tömegú infrastrukturális eszközök váltak kihasználatlanná ugyanakkor a kikötôvárosokban, a nagy energetikai központokban: az orosz erőmüvek egytizede évek óta nem termel, korábban jelentős exportot lebonyolító, több száz kilométer csővezetékrendszer maradt kihasználatlanul. A két orosz emblematikus nagyváros, Moszkva és Szentpétervár infrastrukturális hálózatai ma már nem képesek a gazdasági fejlödés igényeinek eleget tenni.

A Szovjetuniótól örökölt gazdasági alapok is hozzájárultak ahhoz, hogy Oroszország ma meghatározó módon nyersanyag-kitermelő országnak tekinthető. A világpiacon igazán versenyképesnek a nyersanyag-kitermelő régiók tekinthetők. Ezek a térségek vezetik az ország beruházási listáit, ide áramlik a legtöbb tóke és képzett munkaerỏ. Az elmúlt évtized infrastrukturális fejlesztéseinek legnagyobb hányadát is e térségek közúthálózatára fordították, utak épültek a nyersanyag-lelöhelyek, a kikötők és a határátkelök között. Ugyanakkor a korszerü városi infrastruktúra alulfejlettsége jelentős akadályát jelenti e térségek jövőbeni innovatív fejlỏdésének.

$\mathrm{Az}$ új regionális hierarchia azonban nem segíti elő a kohézió erősödését. Az ország elavult közigazgatási szerkezete, a merev területi határok megakadályozzák a kedvező gazdasági és társadalmi folyamatok térbeli terjedését, a vezető régiók nem képesek hatást gyakorolni egyéb térségekre. A területi szegregáció veszteségei nem elhanyagolhatóak (Északnyugat-Oroszország különböző területei együttmúködés hiányában külön-külön fejlesztik például kikötö-iparukat és közúthálózatukat).

A gyenge kohézió egyik megnyilvánulási formája a területi egységek között megmutatkozó nagymértékủ területi különbség. Az egy fóre jutó bruttó regionális termék alapján a legfejlettebb és legszegényebb oblaszty közötti különbség 2004-ben Oroszországban 44-szeres volt (duplája a világ leggazdagabb és legszegényebb országa kỏzötti jövedelmi differenciának). A 89 területi egység közül mindössze 16-ban haladja meg az egy före jutó GDP értéke az országos átlagot (1. ábra). A hét makrorégióra (elnöki meghatalmazott által irányított ún. föderatív körzetre) tagolt országban négy makrorégió teljesítménye ugyan meghaladja az országos átlagot, területi egységeik között azonban nagy szóródás mutatható ki. A négy oblaszty alkotta urali föderatív körzet egy före jutó GDP-je az országos átlag $208 \%$-án van, az itt található legmagasabb teljesítményü orosz terület, a Tyumenyi oblaszty 564\%-os értékével szemben a régió több területi egysége 40-80\%-os átlagon helyezkedik el. A legfejletlenebb déli föderatív körzetben (amelyet nyolc nemzetiségi köztársaság és öt orosz népességủ oblaszty alkot) az egy fơre jutó GDP átlagaa az országos átlag 49\%-át teszi ki. A területi kủlönbségek az ezredforduló után tovább mélyuultek. 1994-ban a legfejlettebb tíz orosz régió egy före jutó GDP-je 2,5-szer, 2002-ben 3,3-szer haladta meg az országos átlagot. 2004-ben a 89 oroš régió közül 10 állította elö az ország GDP-jének több, mint felét (2. táblázat). 


\section{1. ÁBRA}

Az egy före jutó GDP az oroszországi régiókban, 2004 (Oroszország=100)

(GDP per Capita in Russian Regions, 2004 [Russia=100])

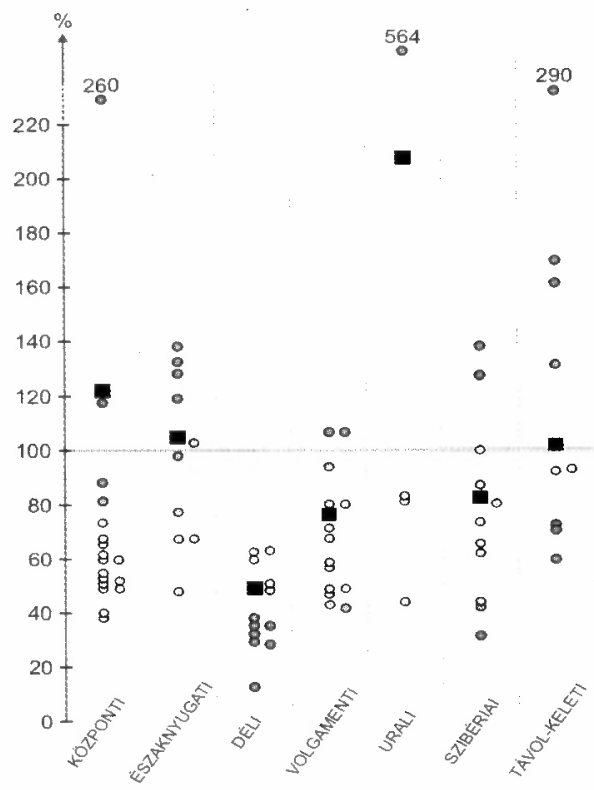

Forrás: Osznovnúe pokazateli szisztemö nacional'nüh szcsotov adatai alapján a szerző szerkesztése.

\section{TÁBLÁZAT}

A tíz legfejlettebb orosz régió részesedése az ország GDP-jéböl, 1994-2004. \% (Percentage Share of the Ten Most Advanced Regions in the National GDP Through 1994-2004)

\begin{tabular}{lclc}
\hline \multicolumn{1}{c}{1994} & & \multicolumn{2}{c}{2004} \\
\hline Terület & Részesedés & \multicolumn{1}{c}{ Terület } & Részesedés \\
\hline Moszkva föváros & 10,2 & Moszkva & 19,0 \\
Tyumenyi & 6,3 & Tyumenyi & 13,0 \\
Szverdlovszki & 3,8 & Moszkvai & 3.8 \\
Moszkvai & 3,6 & Szentpétervári & 3.6 \\
Szentpétervári & 3,2 & Tatarsztan & 2.8 \\
Szanarai & 3.2 & Szverdlovszki & 2.6 \\
Krasznojarszki & 3,0 & Szamarai & 2,5 \\
Nyiznyij Novgorodi & 2,8 & Krasznojarszki & 2,3 \\
Baskíria & 2,7 & Krasznodari & 2,2 \\
Cseljabinszki & 2,7 & Baskíria & 2,1 \\
\hline Összesen & 41,5 & Összesen & 53,9 \\
\hline
\end{tabular}

Forrás: Koncepcija sztrategii szocial'no-ekonomicseszkogo razvitija regionov Roszszijszkoj federacii. 5. o. 
A területi egységek döntő része a globális piacokon gyenge versenyképességet mutat. A korábbi szovjet területfejlesztési politika eredménytelenségét jelzi, hogy az országban egyetlen modern regionális termelési klaszter sem alakult ki. Az orosz régiók egynegyedének gazdaságára a monokultúra a jellemző. A termelési kapcsolatok nem hálózatokban fejlödnek ki, hanem nagy, vertikálisan szerveződött vállalatok irányítják a gazdasági együttmüködéseket. A régen iparosodott, viszonylag diverzifikált gazdasági szerkezetü Tveri terület fafeldolgozó-ipari kibocsátásának 60\%-át négy nagyvállalat adja, a gépipari termelés $44 \%$-át három nagyvállalat állítja elö. Az egyfunkciójú városok legnagyobb számban a Központi régióban, az Uralban és a szibériai területeken találhatók. Az ország 13 régiójában a monofunkcionális városok aránya meghaladja a városi települések $61 \%$-át, s mivel e városok négyötödének népessége meghaladja az 50 ezer föt, a városhálózaton belüli arányuk nem elhanyagolható. Csupán a Szverdlovszki terület monofunkcionális városaiban 1,5 millió ember (a terület városi népességének 42\%-a) él, a Volgogradi, a Tyumenyi és az Arhangelszki területen még kedvezötlenebb a helyzet, ezekben a térségekben a városi népesség több mint fele egy iparág által fenntartott városokban lakik. E mutató alapján Szibéria sincs jobb helyzetben, itt a városi népesség $41 \%$-a koncentrálódik az ilyen típusú városokba (3. táblázat). Mindenekelött e városhálózati sajátossággal magyarázható, hogy az oroszországi befektetések, infrastrukturális fejlesztések zöme a kitermelöiparba és a nagyvállalatokba áramlik, a nemzetközi piacokon versenyképes ágazatok súlya e tekintetben szinte elenyészö.

\section{TÁBLÁZAT}

Nagy számú monofunkcionális várossal rendelkezö területek (Territories Characterised by a Large Number of Monofunctional Cities)

\begin{tabular}{lccc}
\hline $\begin{array}{c}\text { Terület, } \\
\text { köztársaság }\end{array}$ & $\begin{array}{c}\text { A városok } \\
\text { száma }\end{array}$ & $\begin{array}{c}\text { A monofunkcionális } \\
\text { városok száma }\end{array}$ & $\begin{array}{c}\text { A monofunkcionális } \\
\text { városokban élö } \\
\text { népesség aránya, \% }\end{array}$ \\
\hline $\begin{array}{l}\text { Csukcs autonóm } \\
\text { terület }\end{array}$ & 3 & 3 & 100 \\
Hakasz & 5 & 4 & 80 \\
Köztársaság & 13 & 10 & 77 \\
Karél Köztársaság & 16 & 12 & 73 \\
Ivanovoi & 47 & 33 & 70 \\
Szverdlovszki & 20 & 14 & 70 \\
Kemerovoi & 23 & 17 & 68 \\
Nyizsnyij & Novgorodi & & \\
\hline
\end{tabular}

Forrás: Koncepcija sztrategii szocial'no-ekonomicseszkogo razvitija regionov Roszszijszkoj federacii. 9. 0. 


\section{Területi-társadalmi problémák}

Oroszország jelenlegi területi szerkezetére éles demográfiai és szociális egyenlőtlenségek jellemzőek. Mindenekelött a népesség egyenetlen területi megoszlása tekinthető a legnagyobb gondnak. Az ország demográfiai súlypontjának a középnyugati és a délnyugati régiók tekinthetők, a régiók az ország területének negyedét, népességének viszont háromnegyedét teszik ki. Mindez a népsürüségi mutatók szélsőséges különbségeiben mutatkozik meg (2.ábra).

\section{2. ÁBRA}

Az orosz régiók népsürüségi mutatói, 2002, fö $/ \mathrm{km}^{2}$

(Population Density of Russian Regions, 2002, people $/ \mathrm{km}^{2}$ )

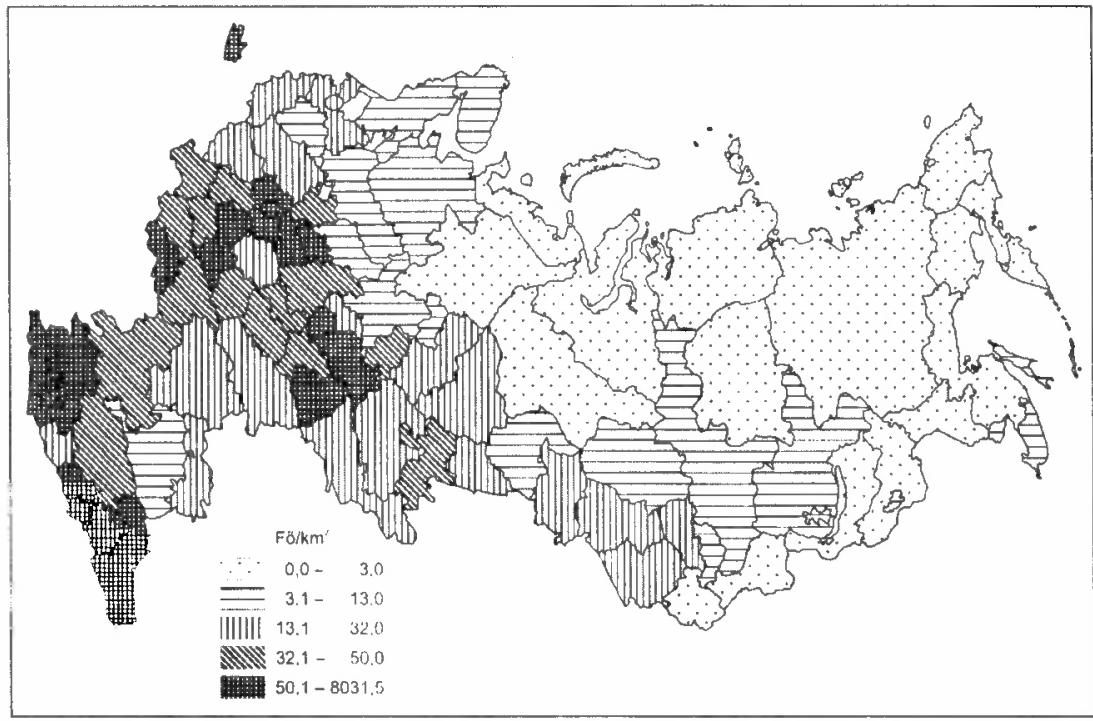

Forrás: Bradshaw-Palacin, 2004. 22. o.

Az erőltetett iparosítás következményeképpen az orosz települések nagy hányada nem képes a népesség normális reprodukciójára. A nagyvárosi agglomerációk demográfiai és migrációs tekintetben hosszú távon stagnálást mutatnak. Az egy millió fő feletti 13 orosz nagyváros közül csupán Moszkva, Rosztov-na-Donu és Volgográd népessége növekszik folyamatosan. Korábban milliós Perm például ki is került ebböl a kategóriából. Az orosz városok népessége 1991-2002 között több mint 4,5 millió fővel (3,9\%-kal) csökkent. Az ipari alapokon nyugvó urbanizáció nyomán új típusú népességreprodukciós jelenségek váltak általánossá, a születésszám és a halálozási ráta csökkent. A természetes szaporodás az ország régióinak többségében folyamatosan mérséklödik. Míg 1990-ben ez a jelenség csupán az elöregedö Központi és az Északnyugati régióban volt megfigyelhető, 2003-ban az ország 73 területi egységére volt jellemzö. E jelenség alól mindössze a keleti és a déli perifériák jelentenek kivételt, ahol a magas születésszám még ma is általános. Több olyan régiója is van az országnak, ahol az elmúlt másfél évtizedben a településállomány egyharmada 
megszünt. Az ország történetében jelenleg fordul elő először, hogy a falu elveszítette önreprodukciós képességét.

Ha a jelenlegi természetes szaporodási ráták fennmaradásával számolunk, akkor 2050-re Oroszország népességvesztesége évi 1,8\%-ot érhet el, a nyugdíjas korú lakosság aránya a 2002. évi 20\%-ról 34\%-ra növekedhet. Mindeközben csökken a munkaképes korú népesség száma is. 2010-ig várhatóan 3,6 millióval lesz kevesebb ember a munkaeröpiacon, számuk 2015-ig 7 millióval szaporodik. Az ország népességének drámai csökkenése és a migrációs tendenciák veszélyt jelentenek geopolitikai szempontból is. Szibériában és a Távol-Keleten demográfiai vákuum keletkezhet, a szomszédos országokból ezt a helyzetet kihasználva tömeges bevándorlásra lehet számítani, ami egyértelmúen ellentétes Oroszország gazdasági és politikai érdekeivel.

A migrációs folyamatok egyoldalúsága - a bevándorlók számának lényeges csökkenése és a kivándorlás állandó emelkedése miatt kialakult kedvezötlen helyzet mellett a regionális fejlödés akadályát jelenti a népesség alacsony mobilitási mutatója is. Több olyan régió is van az országban, amelynek fejlödését komoly munkaeröproblémák akadályozzák. A prognózisok szerint 2006-tól a munkaerőhiány mértéke e régiókban 0,25\%-ról öt év múlva 1,2\%-ra emelkedhet. Ugyanakkor a GDP 7\%-os növekedésének fenntartása hasonló ütemủ munkaképes korú népesség növekedést igényelne. E gondokat a népesség mobilitásának növekedésével lehetne orvosolni. A mobilitást azonban ma számtalan tényezỏ nehezíti:

- A munkaerö-nyilvántartás és a lakásállomány nyilvántartásának nem szerveződtek meg az intézményei. Az emberek nem találnak lakást ott, ahol munkahelyek lennének, és nem találnak munkahelyet ott, ahol laknak;

- Hiányoznak a közszolgáltatások finanszírozási forrásai a népességmegtartásra alkalmas régiókban;

- A magas közlekedési kőltségek akadályozzák a munkaerő ingázását.

Ma Oroszországban a lakosság ingázási szokásai nem igen különböznek a korai iparosítás jellemzőitöl. A kedvezötlen mobilitási mutatókat jelentős részben a munkaerő alacsony képzettsége magyarázza. A képzési rendszer még nem igazodott a piaci körülményekhez, a szakképzés intézményei a szovjet rendszerben épültek ki, nem történtek lényeges változások. Még a dinamikusan növekvő régiókban is egyoldalú kép rajzolódik ki a munkaeröpiacon: nagy hiányok mutatkoznak képzett munkaeröben a müszaki jellegủ tevékenységekben, miközben jelentös túlképzés tapasztalható sok bölcsészettudományi szakmában. A képzés és a gazdaság közötti kapcsolatok nem alakultak ki.

A spontán területi fejlödés következtében az orosz társadalom nagyfokú tagoltságot mutat. Szociológiai felmérések szerint a lakosság 3\%-a tekinthetö gazdagnak vagy milliomosnak, $20 \%$-uk a középosztályba tartozik, a népesség $70 \%$-a sorolható olyan átmeneti csoportba, amelynek tagjai néha megkapaszkodnak, ám gyakran viszsza is csúsznak (közülük legalább $30 \%$ tekinthetö kifejezetten szegénynek) és 10\%-nyi népesség él a rendkívüli szegénységben. Az orosz társadalom szociális megosztottsága hátrâltatja a szociális reformokat, előnytelen hatást gyakorol a belsỏ piac 
bővülésére, a jelenlegi fogyasztási színvonal a gyorsabb gazdasági növekedés akadálya. A lakosság gyenge jövedelmi kondíciói miatt lehetetlen korszerü finanszírozási formákat bevezetni, lakossági hozzájárulásra sem lehet számítani a fejlesztésekben, a civil szerveződések müködése is vontatottan halad.

4. TÁBLÁZAT

Oroszország népességének nemzetiségi összetétele, 2002

(Nationality Makeup of the Russian Population, 2002)

\begin{tabular}{lrcc}
\hline \multicolumn{1}{c}{ Nemzetiség } & Ezer fö & $\begin{array}{c}\text { Megoszlás, } \\
\text { százalék }\end{array}$ & $\begin{array}{c}\text { Az 1989. évi } \\
\text { százalékában }\end{array}$ \\
\hline Orosz & 115869 & 79,8 & 96,7 \\
Tatár & 5558 & 3,8 & 100,7 \\
Ukrán & 2944 & 2,0 & 67,5 \\
Baskír & 1674 & 1,2 & 124,3 \\
Csuvas & 1637 & 1.1 & 92,3 \\
Csecsen & 1361 & 0,9 & 151,3 \\
Örmény & 1130 & 0,8 & 212,3 \\
Mordvin & 845 & 0,6 & 78,7 \\
Belorusz & 816 & 0,6 & 67,5 \\
Avar & 757 & 0,5 & 139.2 \\
Kazah & 655 & 0,4 & 103,0 \\
Udmurt & 637 & 0.4 & 89,1 \\
Azerbajdzsán & 622 & 0,4 & 185,0 \\
Mari & 605 & 0,4 & 94,0 \\
Német & 597 & 0,4 & 70,9 \\
Kabard & 520 & 0,3 & 134,7 \\
Oszét & 505 & 0,3 & 128,0 \\
Dagesztán & 510 & 0,3 & 144,4 \\
Burját & 445 & 0,3 & 106,7 \\
Jakut & 444 & 0,3 & 116,8 \\
Kumi & 423 & 0.3 & 152,4 \\
Ingus & 412 & 0.3 & 191,5 \\
Lezg & 412 & 0,3 & 160,0 \\
\hline Összesen & 145164 & 100,0 & 98,7 \\
\hline Forra, Kon & &
\end{tabular}

Forrás: Koncepcija sztrategii szocial'no-ekonomicseszkogo razvitija regionov Roszszijszkoj federacii. 21. o.

A rendszerváltozás után gyökeres változások következtek be az ország területén élő etnikumok kapcsolataiban is. Míg korábban a soknemzetiségủ birodalom kulturális fejlődését kedvezỏen befolyásolták a nemzetiségi kapcsolatok (a Szovjetunióban az orosz népesség aránya 55\% volt), Oroszország népességének ma már 79,8\%-a orosz nemzetiségủ (4. táblázat). Megszüntek a különbözỏ nemzetiségek regionális oktatási és kulturális intézményei, a kialakuló nemzetiségi enklávék, illetve a nem- 
zeti közösségi léthez szükséges intézmények hiánya az ország régióiban etnikai bezárkózáshoz vezetett. A nemzetiségiek mobilitása igen alacsony értékeket mutat. A nemzetiségi területeken a társadalmi problémák halmozottan jelennek meg, alacsony a gazdasági növekedés és magas a munkanélküliség. A szociális stagnálás politikai konfliktusokat gerjeszt, számtalan esetben a központi kormánynak katonai rendfenntartó erőket kell e térségekbe vezényelnie.

\section{Az orosz településhálózat városi terei}

Az eröltetett iparosítás és a politikai ideológia meghatározott kedvezményezettjei évtizedeken keresztül a városok voltak. Az ország urbanizációs szintje nemzetközi összevetésben is élenjárónak tekinthető, a népesség 74\%-a városokban él. A városi népesség csúcspontját 1990-ben érte el, az orosz városok népességszáma 108,9 millió volt, az azóta folyamatosan zajló csökkenés következtében 2000-re 107,5 millióra mérséklödött. A ritkább benépesültségü területeken értelemszerüen ritka városhálózatot találunk (3. ábra).

\section{3. ÁBRA}

Az orosz nagyvárosok területi elhelyezkedése, 2002

(The Spatial Location of Russian Large Cities, 2002)

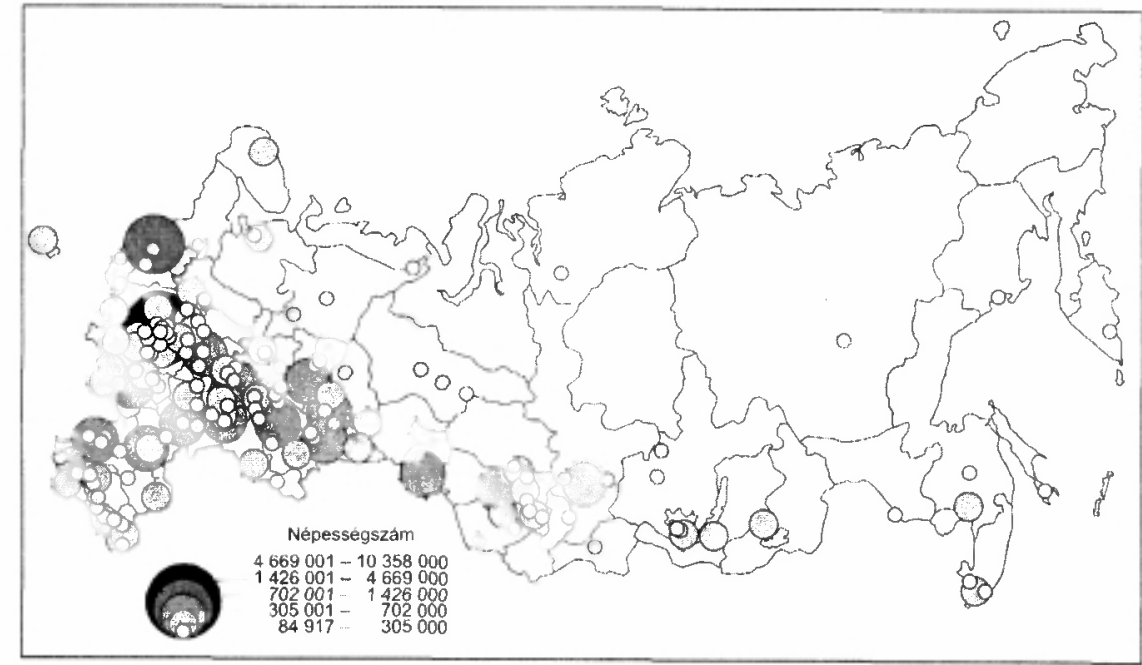

Forrás: Bradshaw-Palacin, 2004. 54. o.

Oroszország a tipikus példája annak, hogy a városodottság foka és a városiasodottság mértéke között ellentmondások keletkezhetnek. Az adminisztratív várossá nyilvánítás feltételeit a szovjet közigazgatási jog mennyiségi, elsősorban a népességszámhoz kapcsolódó követelményekhez kötötte, a városias életforma korszerü infrastruktúrája és intézményei azonban az orosz kis- és középvárosokban szinte teljesen hiányoznak. A rendszerváltozást követően az orosz városállományban is átalakulás kezdődött. A változások mind a városok számában, mind pedig a városi 
népesség számában nyomon követhetök. A városi települések száma Oroszországban csökkent. E szokatlan jelenség oka az, hogy az átmeneti válságperiódusban sok agrárjellegủ város kezdeményezte falusi településsé való visszaminősítését azért, hogy lakosai mérsékeltebb közmüdíjakat fizethessenek, illetve igénybe vehessék az agrártermeléssel kapcsolatos kedvezményeket. A nagyvárosi gazdaságok összeomlása miatt az 1990-es évek közepéig az 500 ezer fỏ feletti nagyvárosok 2,6 millió lakost veszítettek, miközben a 100 ezer fö alatti népességủ városok 1,6 millió fỏvel növekedtek. $\mathrm{Ez}$ utóbbi városok döntő része a déli, gyengén urbanizálódott régiókban és a nemzetiségi területeken található. Általános jelenségnek tekinthetö, hogy a feltörekvő régiókban a városok növekedése folyamatos maradt, a válságtérségekben a krízisjelenségek elsỏsorban a városi tereket sủjtották.

\section{TÁBLÁZAT}

A legnagyobb ipari kibocsátó városok, 1970-1996

(Cities With the Largest Industrial Output, 1970-1996)

\begin{tabular}{lcccc}
\hline \multirow{2}{*}{ Megnevezés } & \multicolumn{2}{c}{$\begin{array}{c}\text { A rangsorban elfoglalt } \\
\text { hely }\end{array}$} & $\begin{array}{c}\text { Az orosz ipari kibocsátásból } \\
\text { való részesedés, } \%\end{array}$ \\
\cline { 2 - 5 } & 1996 & 1970 & 1996 & 1970 \\
\hline Moszkva & 1 & 1 & 5,8 & 8,5 \\
Szentpétervár & 2 & 2 & 2,5 & 5,0 \\
Togliatti & 3 & 64 & 1,9 & 0,3 \\
Cseljabinszk & 4 & 3 & 1,5 & 1,5 \\
Omszk & 5 & 7 & 1,3 & 1,1 \\
Novokuznyeck & 6 & 9 & 1,2 & 1.0 \\
Lipeck & 7 & 30 & 1,2 & 0,5 \\
Szamara & 8 & 6 & 1,1 & 1.2 \\
Ufa & 9 & 10 & 1,1 & 1,0 \\
Cserepovec & 10 & 26 & 1,1 & 0,6 \\
Nyizsnyik Novgoorod & 11 & 4 & 1.0 & 1,5 \\
Szurgut & 12 & - & 0,9 & - \\
Norilszk & 13 & 32 & 0,9 & 0,5 \\
Krasznojarszk & 14 & 8 & 0,9 & 1,1 \\
Magnyitogorszk & 15 & 18 & 0,8 & 0,9 \\
Perm & 17 & 12 & 0,7 & 1,0 \\
Jaroszlavl & 18 & 11 & 0,7 & 1,0 \\
Kazamy & 23 & 15 & 0,6 & 1,0 \\
Jekatyerinburg & 24 & - & 0,6 & - \\
Novoszibirszk & 26 & 16 & 0,6 & 0,9 \\
Rosztov-na-Donu & 45 & 17 & 0,3 & 0,9 \\
Csebokszari & 51 & 14 & 0,2 & 0,9 \\
Ivanovo & 52 & 17 & 0,2 & 1,0 \\
\hline
\end{tabular}

Forrás: Treivish-Brade-Nefedova, 1999. 278. o. 
Az orosz nagyvárosok ipari teljesítöképességében is átrendezödésre került sor. A legnagyobb gazdasági kapacitású 15 orosz város sorrendjének változását szemléltetỏ 5. táblázatból jelentỏs átalakulás olvasható ki. Negyed évszázad alatt Moszkva és Szentpétervár megőrizte pozíciójåt, Nyizsnyij Novgorod viszont a harmadik-negyedik helyröl a tizenegyedikre csúszott vissza, a textilipar fellegvára - az orosz Manchaster - Ivanovo, a jelentỏs gépipari központok, Jekatyerinburg és Rosztov lejjebb kerültek a rangsorban. A diverzikfikált gazdasági szerkezetü Cseljabinszk, Ufa és Szamara képes volt pozíciójának megtartására. Az innovatív (autóipari és petrolkémiai ipari) szerkezetü Togliatti látványos elörelépése a városi rangsorban példaértékü lehet az orosz városfejlesztés számára. A rangsorban szerepeltetett városok 1970-ben az oroszországi ipari kibocsátás 28\%-át, 1996-ban 20\%-át tették ki.

Az orosz nagyvárosi hálózatban korábban vezető pozíciókkal rendelkezó területiközigazgatási központok egy részének dominanciája megszủnt, új versenytársak jelentek meg a régiókbån. A regionális városverseny kialakulása egyben annak is bizonyítékául szolgál, hogy lassan módosulhat az erösen centralizált Oroszországról máig élö kép.

\section{A teriiletfejlesztési politika hiányosságai}

A szovjet korszak területi gazdasági szerkezetében számos egyedi sajátosságot regisztrálhatunk, annak ellenére, hogy az uralkodó államideológia és politika nem ismerte el a térszerkezetet alakító tervgazdasági döntési rendszer eredménytelenségét. A szovjet birodalom területi szerzetének föbb jellemzői a következők voltak:

1) A népesség és a gazdaság (különösképpen az ipar és a szolgáltatások) eröteljes koncentrációja az ország európai területein. A kitermelőipar súlypontja viszont az Uraltól keletre és délre fekvő területek voltak. Az 1980-as évek közepén évente 1 milliárd tonna nyersanyag áramlott a keleti térségekböl a nyugati iparvidékekre, 3000 kilométeres szállítási távolságra. Szibéria és a Távol-Kelet iparfejlesztési programjai kizárólag a nyersanyagok eJőállítására korlátozódtak, különleges eszközökkel ösztönözték a munkaerö helyben maradását. $\mathrm{E}$ megoldások rendkívül drágák és eredménytelenek voltak.

2) Szélsőséges, specializációs regionális fejlesztési programok kivitelezése a gigantománia jegyében az ágazati minisztériumok erőfölényének demonstrálása érdekében. Több régióban és sok városban a fejlődést egyetlen kitermelóipari ágazatra alapozták Például Ivanovo területen az ipari kibocsátás döntó részét a textilipar, az Udmurt Köztársaságban és számtalan szibériai városban a hadiipar szolgáltatta. A területi koncentrációt vállalatszervezési eszközökkel is elösegítették, az innováció érzékeny feldolgozóipari ágazatokban hatalmas monopóliumok jöttek létre. 1990-ben közel ezer nagyvállalat uralta a szovjet feldolgozóipart. 
3) A települések autonóm müködési feltételei korlátozottak voltak, a szociális szféra a nagyvállalatok befolyása alatt állt. Magnyitogorszk városüzemeltetését kizárólag a vaskombinát, Togliattiét az autógyár látta el, és hosszan lehetne a példákat sorolni.

4) A formálisan föderatív, lényegében azonban unitárius állam tagköztársaságai korlátozott gazdaságfejlesztési hatáskörökkel rendelkeztek.

A rendszerváltozást követően a szovjet típusú területfejlesztés szinte minden alapeleme megroppant. A gazdasági dezintegráció legnagyobb vesztese a mesterséges integrációból korábban egyértelmüen hasznot húzó Oroszországi Föderáció lett. Az orosz gazdaság regionális állapotára is eröteljes hatást gyakorló dezintegráció a következő jellemzőkkel írható le:

1) A szállítási tarifák emelkedése, a termékstruktúrák elértéktelenedése, a fogyasztás visszaesése és az új irányú gazdasági kapcsolatok létrejöttének lehetőségei következtében a régióközi árucsereviszonyok lényegesen átalakultak. A régiók közötti termékforgalom összezsugorodásának mértéke felülmúlja a termeléscsökkenés mértékét.

2) A régiók költségvetése összeomlott, a folyamatos forráshiány és az egyre fokozódó adósságállomány fokozta a központi kormány és régiók közötti ellentéteket.

3) A bevételnövelés maximalizálása a nyersanyagok gátlástalan kitermelését eredményezte, a régiók gazdasági szeparatizmusa általánossá vált.

4) A régióközi munkaáramlás a közlekedési költségek megemelkedése miatt minimálisra csökkent.

Az egységesnek deklarált orosz államtérben a kommunizmus bukása után gazdasági és politikai értelemben egyaránt divergens folyamatok indultak el. A politikai tényezök sorában jelentős szerepe van a központi kormányzat és a régiók közötti hatalommegosztásnak. Az új orosz alkotmány elvben szabályozta a hatalmi viszonyokat és felszámolta a régiókat sújtó diszkriminatív szabályok többségét. Az 1998. évi gazdasági válság ugyanakkor azt is érzékeltette, hogy a gazdasági összeomlást nem lehet csupán politikai eszközökkel megakadályozni, a piaci alapokon szerveződő integrációt gazdaságpolitikai eszközökkel kell támogatni. Ekkortól beszélhetünk a regionális gazdaságpolitika felértékelödéséről. A regionális politika fogalma 1992-ben jelent meg először az orosz kormányzati dokumentumokban. Borisz Jelcin ebben az évben fordult regionális politikai elnöki üzenettel az orosz parlamenthez. Az alsó- és felsőházban regionális politikai bizottság jött létre. A politikai pártok programjaiban is megjelentek a területfejlesztés problémái. 1996-ban Jelcin elnök állásfoglalást bocsátott ki „Az Oroszországi Föderáció regionális politikájának fö irányairól". 
Az elnöki dokumentum a regionális politika céljait, eszközeit és intézményeit vette sorra. Fontosabb elemei a következők voltak:

- Ki kell dolgozni a föderalizmus gazdasági, szociális, jogi és szervezeti elveit;

- Az alkotmányos szabályozásból kiindulva meg kell határozni a szociális biztonság alapkövetelményeit függetlenül attól, hogy az egyes régiók milyen fejlödési potenciállal rendelkeznek;

- Esélyegyelöséget kell teremteni az ország régióiban;

- Regionális környezetvédelmi programokat kell készíteni;

- A stratégiai jelentőségü régiók fejlesztésére kiemelt figyelmet kell fordítani;

- Maximálisan ki kell használni a régiók klimatikus és természeti adottságait;

- Meg kell teremteni a helyi önkormányzatok müködési feltételeinek garanciáit.

E feladatsor ugyan nem sokban különbözött a szovjetrendszer területpolitikai céljaitól, mégis jelentös eredménynek lehet tekinteni, úgy is, mint a korszerú regionális politika nyitányát Oroszországban. A dokumentum széleskörủ társadalmi vitákat váltott ki, elindult az orosz közigazgatási rendszer továbbfejlesztését kezdeményező párbeszéd is, elsösorban politikai és szakmai körökben.

A regionális politikai feladatok finanszírozására az orosz duma létrehozta a föderatív területi egységek támogatási alapját, amelynek forrása a vám- és importilletékek nélkül számított adóbevételek $15 \%$-a volt. Az alap felhasználásnak alapvető célja az akut problémákkal küszködő régiók támogatása lett volna, ám támogatásban szinte valamennyi régió részesült, a 89 területi egység közül 81 részesedett e forrásokból. A támogatások jelentös részét költségvetési problémák megoldására fordították.

A területfejlesztési intézményrendszer müködésének stabilitását sem sikerüßt megteremteni. Az orosz gazdaságpolitika meghatározó intézményében, az elnöki hivatalban nem alakult regionális politikai egység, a központi adminisztrációban kezdetben a gazdasági minisztérium lett a regionális politika felelöse. Éves kormánybeszámoló összeállításában lényegében ki is merültek feladatai. Az 1990-es évek közepén új központi szerv, a Föderatív és Nemzetiségi Ügyek Minisztériuma lett a regionális politika felelöse, 2000-töl pedig önálló Regionális Fejlesztési Minisztériumot szerveztek. Az orosz regionális politika első szakaszában - egybehangzó szakértői vélemények szerint - mindössze formai eredményekről lehet beszámolni, polgárjogot nyert a részpolitika fogałma, intézménye megjelent a központi közigazgatásban. Konkrét eredmények mindössze néhány regionális program kidolgozásában jelentek meg (Artobolevskiy 2000).

$\mathrm{Az}$ államháztartás stabilizálása és a felgyorsuló gazdasági növekedés az 1990-es évek végétöl lehetővé tette, hogy az állam jelentősebb eszközöket fordítson a területi különbségek mérséklésére. A fél évtized tapasztalatai azonban egyértelmüvé tették, hogy az állami regionális politikai eszközök nem hatékonyak, az alkalmazott eszköztár kimerítette a kezdeti idöszakban eredményekkel kecsegtető lehetöségeit. A regionális politika alkalmazásában az orosz állam újabb kihívásokkal találta magát szemben. Míg korábban, az elsődleges iparositás időszakában a területi küłönbségek 
mérséklését a szabványosított tömegtermékeket elöállító, nagy munkaerökoncentrációt igénylő ipari létesítmények telepítésével kívánták megvalósítani, az új politikának a piacnyitás és a belsỏ piac bővítésén nyugvó különbségmérséklési stratégiát kellett alkalmaznia. A piaci viszonyokhoz való alkalmazkodásban lemaradt régiók költségvetésből kapott kiegyenlítési támogatásai a nemzetgazdasági hatékonyságot egyértelmúen rontották, hiszen a vezetô régióktól jelentős erőforrásokat vontak el az újraelosztás céljából. Ez a mechanizmus kedvezötlen helyzetbe hozta a fejlett régiókat is, nem voltak képesek a nemzetközi piaci versenyhez alkalmazkodni. A kiegyenlítés, mint regionális politikai célkitüzés akadályt jelentett az innovációk területi terjedésének ösztönzésében és a versenyképességi követelmények teljesítésének támogatásában is. A vezetô régiók csak korlátozottan érvényesíthették fejlesztési motivációikat, a támogatott régiókban pedig az eltartottság érzése rontotta a közhangulatot.

A regionális politika eszköztára is szegényes volt, állami transzferek és célprogramok alkották az alkalmazott eszközök nagyobb hányadát. A korszerü regionális politikai eszközök csak lassan és korlátozott mértékben jelentek meg az állami politikában. A közigazgatási reformok és az államháztartás átalakítása csak makroszinten éreztette hatását. A mezoszint érintetlen maradt, nem alakultak ki a regionális fejlesztés feltételei. Nem készültek átfogó elemzések a régiók helyzetéröl, nem határoltak le különbözỏ fejlettségi típusokat, nincsenek információk a regionális sajátosságokról. E hiányosságok miatt nem lehet differenciált regionális politikát alkalmazni. A területi közigazgatási egységek tervezési rendszere fejletlen, nincs összhang a település- és a területi tervezés között. A régiók közötti együttmúködés szinte ismeretlen fogalom Oroszországban, a költségvetési források hasznosítására nincsenek érvényes alapelvek és szabályok. Az országnak nincs területfejlesztési stratégiája, az állam elképzelései a szegénység visszaszorításáról, a bruttó hazai termék növeléséröl, az iparilag hanyatló térségek korszerúsítéséröl és az egységes országról vallott állami döntések területileg differenciált és konkrét elképzeléseket ezért nem is tartalmazhatnak. Az egyes régiók fejlödésére hatást gyakorló intézkedések kizárólag a minisztériumok és föhatóságok kompetenciájába tartoznak, a hatóságok között egyeztetési mechanizmusok nem múködnek. A területi tervezési kultúra alacsony színvonalon van, a korábbi tervezési módszerek és megoldások is feledésbe merültek. Az ország új területi szerveződésének hatásai nem jelennek meg a jogalkotásban és a költségvetési tervezésben. Az 1994-ben elfogadott országos településhálózat-fejlesztési koncepciót sem az üzleti szféra, sem pedig a helyi hatalmi szervek nem veszik figyelembe.

Az ország területi közigazgatási rendszere elavult. A közigazgatási határok akadályozzák az új típusú fejlődést, méretgazdaságossági követelményeknek sem tesznek eleget. A régiók jogi szabályozása nem felel meg a nemzetkőzi normáknak, az ország szinte egyetlen európai területi egyưttmúködést sem ratifikálı. A 89 területi-közigazgatási egységböl szervezett hét föderatív körzet ma még kizárólag a központi hatalom - pontosabban az elnöki intézmény - dekoncentrált szerveként múködik (4. ábra). 


\section{4. ÁBRA}

Föderatív körzetek Oroszországban

(Federative Regions in Russia)

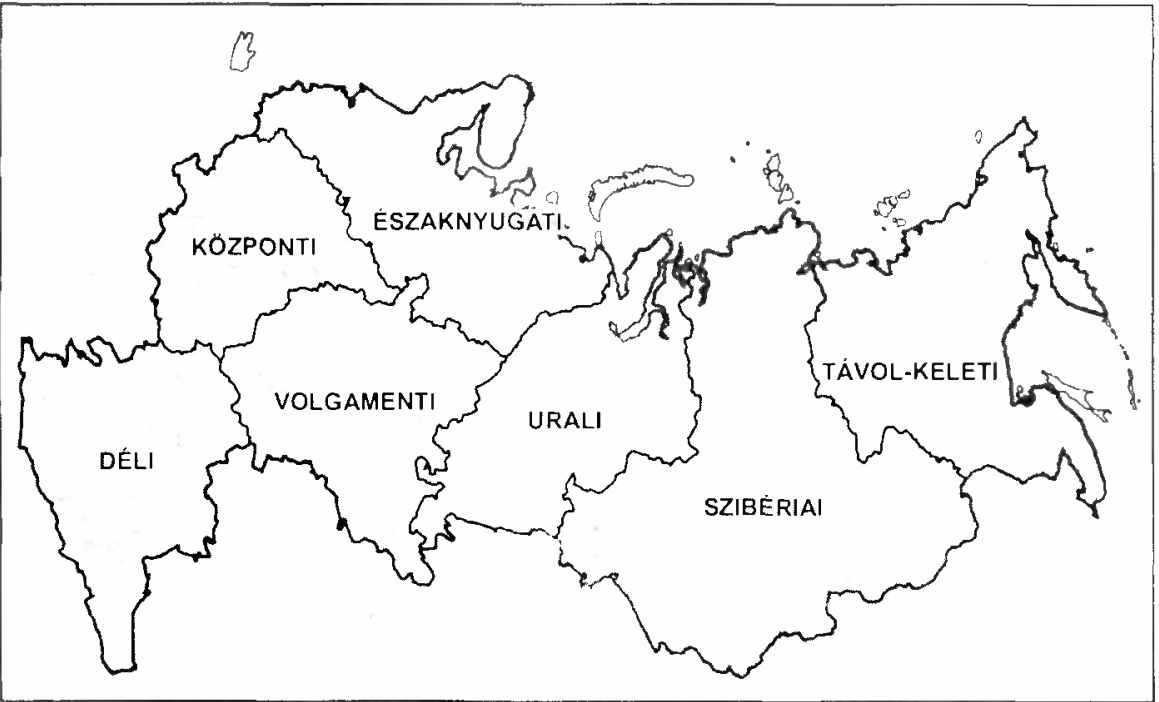

Forrás: Saját szerkesztés.

\section{Az új területfejlesztési stratégia alapjai}

A Regionális Politikai Minisztériumban 2005-ben készült el az ország területfejlesztési stratégiája (Koncepcija sztrategii szocial'no-ekonomicseskogo razvitija...). A nyolc fejezetbỏl álló dokumentum helyzetképet ad az ország regionális különbségeiröl, vázolja a regionális politikával szemben támasztott követelményeket. A dokumentum a modern regionális politika alapelveit a következőkben határozza meg:

1) Többpólusú fejlesztéspolitika. A területi különbségek mérséklését szolgáló intézkedéseket az egyes régiók sajátosságainak megfelelóen kell kialakítani. A fejlesztési erőforrásokat olyan pólusokba kell összpontosítani, amelyek alkalmasak innovációs folyamatok elindítására és fenntartására. Mivel az ország modernizációja a kezdeteknél tart, az innovatív intézkedéseket növekedési központokba célszerü összpontosítani. E politika megvalósítása érdekében mintarégiókat célszerú kijelölni (6. táblázat).

2) Komplexitás. Az esélyegyenlőség alkotmányban rögzített elvének érvényesítése, az országos kohéziós célok teljesítése érdekében a korszerü programok megvalósításából kimaradt régiók számára költségvetési eszközöket kell átcsoportosítani. A priorizált növekedési pólusokon kívül elhelyezkedő, elmaradott térségeket sem szabad magukra hagyni. Az elmaradott térségekre is fejlesztési koncepciókat kell kidolgozni. A központi föderációs szervek 
feladata az, hogy a regionális fejlesztési forrásokat differenciáltan, a reformokat szolgáló preferenciák figyelembevételével határozza meg.

3) Komplementer hatékonyság, szinergia. A regionális politikai célokat az országban zajló egyéb reformokkal szoros összhangban kell meghatározni. A területfejlesztési támogatások elosztása során tekintetbe kell venni a régiók együttmüködését, az egyes támogatási formák összehangolására van szuikség.

4) A regionális politika differenciálása. Oroszország bekapcsolódása a globális integrációba az ország térségeit különbözőképpen érinti. Az egyes térségek fejlödési potenciáljában és adottságaiban jelentös eltérések tapasztalhatók. Az egyes tértípusokban változatos és differenciált eszközökre lesz szükség (7. táblázat).

5) Szubszidiaritás. A régiók társadalomi és gazdasági fejlesztésében a helyi szerveknek nagyfokú önállóságot kell kapniuk. Ennek legátfogóbb módja a hatal mi jogkörök decentralizálása.

\section{TÁBLÁZAT}

A polarizált regionális fejlesztés elemei

(Elements of Polarised Regional Development)

\begin{tabular}{lll}
\hline \multicolumn{1}{c}{ Állami politika } & \multicolumn{1}{c}{$\begin{array}{c}\text { A regionális kiülönbségek } \\
\text { mérséklése }\end{array}$} & \multicolumn{1}{c}{$\begin{array}{c}\text { Polarizált regionális } \\
\text { fejlesztés }\end{array}$} \\
\hline Alapcél & $\begin{array}{l}\text { Az ország különbözö részein } \\
\text { beavatkozási régiók kijelölése }\end{array}$ & $\begin{array}{l}\text { Növekedési régiók } \\
\text { lehatárolása }\end{array}$ \\
$\begin{array}{l}\text { Területi- } \\
\text { közigazgatás }\end{array}$ & $\begin{array}{l}\text { A közigazgatási határokhoz } \\
\text { igazodó, területileg kompakt } \\
\text { egységek kijelölése }\end{array}$ & $\begin{array}{l}\text { A mintarégiók jogi } \\
\text { szabályozásának } \\
\text { kialakítása }\end{array}$ \\
Szabályozási feladat & $\begin{array}{l}\text { A támogatási területek közötti } \\
\text { arányos forráselosztás }\end{array}$ & $\begin{array}{l}\text { Álla források juttatása a } \\
\text { mintarégiók innovációs } \\
\text { potenciáljának fejlesz- } \\
\text { tésére, a globális gazda- } \\
\text { sághoz való kapcsolódás } \\
\text { ösztönzésére }\end{array}$ \\
\hline
\end{tabular}

Forrás: Koncepcija sztrategii szocial'no-ekonomicseszkogo razvitija regionov Roszszijszkoj federacii 25. o. 


\begin{tabular}{|c|c|c|}
\hline \multicolumn{3}{|c|}{$\begin{array}{c}\text { 7. TÁBLÁZAT } \\
\text { Az egyes tértípusok problémái és fejlesztési feladatai } \\
\text { (Problems and Development Tasks of Specific Spatial Structure Types) }\end{array}$} \\
\hline Térszerkezeti típusok & A régiók fejlödési problémái & Megoldandó feladatok \\
\hline $\begin{array}{l}\text { Nyersanyag-kitermelö } \\
\text { térségek }\end{array}$ & $\begin{array}{l}\text { Infrastrukturális elmaradott- } \\
\text { ság. környezeti és település- } \\
\text { fejlesztési érdekkonfliktusok }\end{array}$ & $\begin{array}{l}\text { Humánerőforrás-fejlesztés. } \\
\text { Munkaerö-betelepítés. Infra- } \\
\text { struktúra-fejlesztés. Környezet- } \\
\text { védelmi programok. Hatékony } \\
\text { telephely-politika }\end{array}$ \\
\hline
\end{tabular}

Veszélyeztetett övezetek

- Határ menti térségek

- Nemzetiségi területek

- Etnikai konfliktusok sújtotta területek

- Az államrendet és az ország integritását veszélyeztetö területek

Technológiai transzferterületek

Innovativ térségek

Nemzetközi jelentőségü városok

Régi ipari térségek

Ưjonnan iparosított területek
Nagymértékủ népességelvándorlás. A szociális infrastruktúra szükülése. Hiányos kommunikációs hálózatok.

Gyenge kulturális kölesönhatások. Identitásból fakadó konfliktusok. A közrendet veszélyeztető problémák.

A népesség biztonságát és életét, az államrendet és az ország integritását veszélyeztetö események.

Munkaeröhiány. Ipari területek hiánya. Gyengén fejlett infrastruktúra. Szegényes üzleti szolgáltatások.

A nemzeti innovációs rendszer regionális komponenseinek hiánya. Gyenge piacszervezési intézmények. Kvalifïkált munkaerö hiánya

Oroszországban a globális versenyben sikeresen szerepelni képes nemzetközi városok száma korlátozott. A városhálózat elavult. a települések együttmúködése gyenge.

Alacsony színvonalú életkörülmények. Elavult müszaki létesítmények. Gyenge piaci kapcsolatok. Szakképzettség hiánya.

Magas munkanélküliség. A városfejlödés gyenge infrastrukturális alapjai. Nagymértékủ szociális konfliktusok. Alacsony fejlettségi szint.
Határokon átnyúló együttmüködési formák szervezése. Közlekedési, kulturális és logisztikai központok alapításá. A munkaeröforrások bövítése, A népességszám stabilizálása. Infrastruktúrafejlesztés. A szociális biztonsági intézmények megerōsítése. A jogi szabályozás felülvizsgálata. A határrendészeti szervek megerösítése, a közbiztonság fokozása.

Fejlett technológiák importja. Stratégiai befektetök ösztönzése. Humáneröforrás-fejlesztés.

Regionális innovációs stratégiák kidolgozása. A kommunikáció fejlesztése. Munkaeröképzés. Technológiai transzferközpontok szervezése.

Nemzetközi vállalati központok betelepítése. Az infrastrukturális fejlesztések meggyorsítása. Magus szintü városi környezet kialakítása. Föderatív jelentöségú igazgatási és szolgáltatási intézmények telepítése. Ipari parkok szervezése, Újraiparosítás. A régi ipari települések rehabilitálása. A gazdaság diverzifikálása.

A népesség vándorlását és adaptációját szolgáló programok. Foglalkoztatás növelö intézkedések. Költsêgvetési források bỏvítése. Infrastruktúra fejlesztése.

Forrás: Koncepcija sztrategii szocial'no-ekonomicseszkogo razvitija regionov Roszszijszkoj federacii 27-28. o. 
A regionális koncepciótervezet leszögezi, hogy az ország modernizálása, a hazai össztermék növelése a régiók aktivitásának fokozásával érhető el. A központi, föderatív szintű regionális politika céljait az alábbiakban fogalmazza meg:

1) javítsa az Oroszország területén élő népesség életkörülményeit,

2) teremtse meg a tartós és jó minőségủ gazdaságfejlesztés feltételeit,

3) erősítse Oroszország és régiói versenyképességét a nemzetközi piacokon.

A regionális politika stratégiai céljait a tervezet a következőkben rögzíti:

1) Oroszország és régiói versenyképességének megteremtése. A piacgazdaság szempontjait figyelembe véve a gazdaság és a településhálózat összehangolt fejlesztésével megnyitni az utat a gazdasági növekedési források eléréséhez. Átfogó infrastruktúrafejlesztési programokat kell kezdeményezni. Nemzetközileg versenyképes termelési klaszterek szervezése az innováció igényes ágazatokban.

2) UUj regionalizációs folyamatok ösztönzése, a regionális eröforrások újbóli számbavétele. A területi kohéziót és az egységes nemzeti gazdasági térség fejlesztését a regionális és a helyi önállóság tiszteletben tartásával célszerủ alakítani. A munkaerő, az áruk és a szolgáltatások szabad áramlása előtti akadályokat fel kell számolni, meg kell nyitni a regionális piacokat. Támogatni kell a kis- és középvállalkozásokat.

3) Az emberi eröforrások fejlesztése, a népesség térbeli és ágazati mobilitásának fokozása. Az ország népességreprodukciós mutatóinak javitása, a fiatal családok gyermekvállalási kedvének anyagi ösztönzése. Az oktatási rendszer fejlesztésével növelni kell a térségek szakképzett munkaerö-állományát, a népesség stabilitását. Migrációs programokat kell kidolgozni az egyes térségek demográfiai és foglalkoztatási folyamatainak összehangolására, a migránsok orosz társadalomba való beilleszkedésének elősegítésére. Fejleszteni kell az orosz lakosság etnokulturális magatartását.

4) A régiók ökológiai állapotának javitása. A gazdaságfejlesztési programokat környezetvédelmi elemzéseknek kell alávetni. Energia- és nyersanyagtakarékos technológiákkal kell javítani a térségek ökorendszereit.

5) $A z$ államigazgatás minöségének javítása, költségvetési reformja a régiókat alkotó területi egységekben. Az államigazgatási szervek ösztönzése új irányítási módszerek (stratégiai tervezés, hatékonyságnövelö intézkedések, együttmüködési formák, public-private partnership) alkalmazására.

A dokumentumtervezet öt regionális fejlesztési prioritást határoz meg. Mindenekelött aláhúzza annak igényét, hogy a különbségmérsékelỏ politikáról a lehető leggyorsabban a polarizált fejlesztési politikára kell áttérni. A koncentrált fejlesztési politikához ki kell jelölni az ország különbözỏ fokozatú (nemzetközi, regionális, járási) növekedési központjait. Húzó régiókként azok a területi egységek vehetök számításba, amelyek a) magas áru- és utasforgalmi mutatókkal jellemezhetők, b) nemzetközi és országos jelentőségủ tudományos és felsőoktatási intézményeik 
vannak, c) olyan kezdeményezések születtek, amelyek országos jelentöségủek, d) gazdasági növekedésük országos átlag feletti, e) magas színvonalú szellemi tökével és képzett szakemberállománnyal rendelkeznek, f) stratégiai partnerség épült ki vagy viszonylag megteremthető az államigazgatás, a civil szféra és a gazdaság szereplöi között, g) egy évtizeden belül alkalmassá válhat a szomszédos térségek fejlődésének ösztönzésére.

A dokumentum második prioritásként a nemzeti innovációs rendszer regionális elemeit említi. Ezek sorában több lehetöséget is említ: a zárt területi képzödmények (hadiipari komplexumok) integrálását a regionális gazdaságokba, a hét orosz tudományos város erỏteljes támogatását technológiai transzferközpontok kialakítására, regionális kutatóegyetemek kijelölése (az alapkutatások és a kutatási transzferek támogatása), különleges gazdasági övezetek szervezése a prosperáló régiókban.

A koncepció harmadik prioritása az ipari modernizáció és versenyképes ipari klaszterek szervezése. Az új - a hálózatos gazdaság fejlesztését szolgáló - iparszervezési lehetőségek alkalmazása komoly nehézségek elé állítja majd a hagyományosan vertikális szervezett orosz ipart. Az új gazdaság támogatása ezért nagy volumenủ állami segítséget igényel majd.

A negyedik prioritás foglalkoztatáspolitikai és népesség mobilitási feladatokat tartalmaz, a korszerủ európai gyakorlat számtalan eszközét és intézményét sorolja fel.

$\mathrm{Az}$ ötödik prioritás államigazgatási és költségvetési kérdéseket érint. A napirenden lévö közigazgatási modernizációs programokban is szerepel a tárcaközi együttmüködés szervezeti átalakítása, a monitoring rendszerek kiépítése. A költségvetési szféra reformja jelenti a legnagyobb kihívást. A teljes önkormányzati finanszírozási rendszert át kell alakítani.

A stratégiai koncepció megvalósítását szolgáló lépés volt a Regionális Politikai Minisztérium keretei között létrehozott tárcaközi bizottság, amely alapvetöen puha egyeztetési feladatokat lát el, és felkészül a koncepció végrehajtásának ellenörzésére, és müködteti majd a monitoring hálózatot. A koncepció javaslatot tesz föderatív területfejlesztési ügynökség felállítására, amely tanácsadási és konkrét szervezési feladatokat látna el a regionális és ágazatközi programok végrehajtásában, illetve forráskoordinációt is ellátna. A másik felállítandó intézmény, az országos területi és várostervezési intézet holding formában a regionális tervezés meghatározó szereplöje lenne.

A stratégiai koncepció kijelöli a végrehajtás menetrendjét is. Eszerint az első szakaszban (2005-2008) kutatások folynak, és a prioritások régiókkal való egyeztetésére kerül sor. Kísérleti régiókat jelölnek ki, és megszervezödik az elöbb említett intézményekben a monitoring hálózat. A második szakaszban (2007-2010) a mintarégiókban kiépítik az új politika teljes eszköztárát, bevezetik az állami támogatások új rendszerét és regionális célprogramokat indítanak. A harmadik szakaszban (2011-2020) egyre több régió lép az új rendszerbe, és az orosz regionális politika cél-, eszköz- és intézményrendszere általánossá válik. 


\section{Irodalom}

Alexander, J. (2000) Federal reforms in Russia: Purin's challenge to the Republics. Kézirat. Artobolevskiy, S.S. (1995) Regional'naja politika "Roszzii. Kézirat. Moszkva.

Artobolevskiy, S.S. (1997) Spatial disparities and regional policy in modern-day Russia. Artobolevskiy, S.S.-Bachtler, J. (szerk.) European Integration and Economic Transition. Challenges for Reginnal Policy. Tacis Srevices, Brussels.

Artobolevskiy, S.S. (2000) Recent trends in Russian regional policy and use of then EU countries experience. - Horváth Gy. (szerk.) Regions and Ciries in the Global World. Centre for Regional Studies, Pécs. 192-201. o.

Bandman. M.K.-Gruzner, S.S.-Seliverstov, V.E. (1999) Federal'naja pomoscs depreszszivnüm i otsztal'nüm regionam Roszszii. - Federalizm i Regional'jya politika, 3. 188-231. o.

Bradshaw, M.J.-Palacin, J.A. (2004) An Atlas of the Economic Performance of Russia's Regions. University of Birmingham, Birmingham.

Bülov, G.V.-Smirjagin, L.V. (1996) Programma pomoscsi regionam (Projekt koncepció) - Federalizm i regional naja politika. 3. 172-185. o.

Dabla-Norris, E.-Weber, S. (2003) Regional Disparities and Transfer Policies in Russi. Theory and Evidence. International Monetary Fund, Washington.

Doklad o szoversensfrovanii mehanizma federotivniih otmosehnij. (2005) Goszudarstvennüi szovet Roszszijszkoj Federacii, Moszkva.

Hanson, P.-Bradshaw, M. (szerk.) (2004) Regional Economic Change in Russial. Edwin Elgar, Cheltenlam.

Kennaway, A. (1999) Confinuiry and conflict in Russian Government. Royal Military Academy, Camberley.

Koncepcija sztrotegii szocial'no-ekonomicseszkogo razitija regionov Rosaszijszkoj federacii. (2005) Ministerstvo Regional'nogo Razvitija. Moszkva.

Lavrov, A. (1994) Bjiudzsetiij federalizm v Rozsszii. Analiticseszkij Centr pri Prezidente Roszszijszkoj Federacii, Moszkva.

Lavrov, A.-Shuvalov, V. (szerk.) (1999) Predprinimetel'szkjy klimat regionov Roszszii. Nacsala Press. Moszkva.

Novikov, A. (1998) Risk Factors Associated with Russian Regions and Municipalities. Institite for Urban Economics, Moscow.

Orttung, R. (2000) The role of regional executiles in Russian politics. The National Council for Euroasian and East European research, Washington.

Ozornoy, G.1. (1995) Spatial inequality in the Gorbatsev 's era, - Hardy, S.-Hart, M. (et al) An Enlarged Europe. Regions in Competition? Jessica Kingsely, London, 207-228. o.

Osznovnite pokazateli szisztemii nacional'niih szcsıtov. (2005) Federal'naja szluzsba goszudarsztvennoj sztatisztiki, Moszkva.

Roseth, T. (2001) Regionalisation: Disadvantageous for the development of sub-national donocracy? Bergen, University of Bergen.

Roszszijskoe ekspertnoe obozrenie. 7. Regional'naja politika Roszszii. 2005.

Roszsizjszkoe ekspertnoe obozrenie. 10. Prostranstvennoe razvitie Roszszii. 2005.

SOPS and Gosplan (1992) Methodical recommendations on the elaboration of sectoral schemes of development and allocation of productive forces. Moscow.

Stroev, E.-Bliakhman, L.-Krotov, M (1999) Russia and Eurasia at the crosstoads: experience and problems of economic reforms in the Commonwealth of Independent States. Springer Verlag, BerlinNew York.

The Territories of the Russain Federation. An Extensive Rederence Survay of the 89 Constituent Units of the Russian Federation. (1999) Europa Publications, London.

Tóth K. (1997) Kelet-Európa üj alkotmányai. JATE Állam- és Jogtudományi Kara, Szeged.

Treivish, A.-Brade, I--Nefedova, T. (1999) Russian cities at the corssroads. - GeoJournal. 1. 115-127. o.

Weiner Cs. (2004) Oroszország gazdasága a XXl. század elcjén. Fiiggóség. Mühelytanulmányok. 60. MTA Világgazdasági Kutatóintézete, Budapest.

Westund, H.-Granberg, A.-Snickars, F. (szerk.) (2000) Regional Development in Russia. Past Policies and Future Prospects. Edwin Elgar, Cheltenham. 


\section{RUSSIA OF THE REGIONS}

\section{GYULA HORVÁTH}

Russia inherited from the Soviet Union an economic structure that was geographically highly unbalanced. Capital accumulation and industrial location were a result of a concerned government policy to locate key industry in a small number of regions. But even after the collapse of the Empire, the gap between more prosperous regions, including Moscow and St. Petersburg, and less developed ones, has not been reduced. Actually, the gap has widened during the last decade of transition. The paper describes regional disparities and their influencing factors, analyses regional socio-economic imbalances, losers and winners of the transition. Finally, it gives a summary of regional development policy documents and main targets of the regional policy. 